\title{
Tolerance of mango ginger (Curcuma amada Roxb.) against sodic stress soil: Effects on growth, rhizome yield, water relation, photosynthetic pigments, antioxidative enzymes, cations and heavy metals concentration
}

\begin{abstract}
To assess the salt tolerance status and mechanism in medicinal plants, a soil pot experiment was conducted on Curcuma amada Roxb (mango ginger). The rhizomes of this plant have highly medicinal value and are useful in different diseases. The plants were raised on natural sodic soils having different levels of ESP i.e., 4.37 (control), 15.7 (low), 35.6 (medium) and 54.5 (high) with four replicates in complete randomized design. Results indicated that plant growth, rhizome yield and biomass were significantly decreased in medium and high ESP level. The cell sap EC and water potential (became less negative) were increased than the control while cell sap $\mathrm{pH}$ and water saturation deficit decreases up to medium ESP then increased at high ESP while RWC and SWC increased up to medium ESP and at high ESP decreases. Anti-oxidative enzymes like CAT, SOD and GR were increased on increasing the soil sodicity while POX activity decreases. Some non-enzymatic anti-oxidant like total phenol and prolien contents were increased while $\mathrm{H}_{2} \mathrm{O}_{2}$ content was reduces on increasing the soil sodicity. The concentration chlorophylls, carotenoid and carotenoid /chlorophyll ratio were decreased on increasing ESP. The reducing sugars content was decreased while total carbohydrate and protein content increases. Maximum concentration of $\mathrm{Na}$ was observed in leaf and least was observed in rhizome. The cations i.e., $\mathrm{Na}, \mathrm{Pb}$ and $\mathrm{Mn}$ were significantly increases on increasing the soil sodicity in all parts of plant while $\mathrm{K}, \mathrm{Fe}, \mathrm{Cu}$ and $\mathrm{Zn}$ concentration were observed decreased on increasing soil sodicity in different plant parts. $\mathrm{Na} / \mathrm{K}$ ratio least observed least in rhizome while highest in root.
\end{abstract}

Keywords: salt tolerance, water potential, metabolism, photosynthetic pigments, rhizome
Volume 2 Issue 6 - 2018

\author{
Pramod Kumar Singh,' Shalini G Pratap,' \\ Pramod Kumar Tandon ${ }^{2}$ \\ 'Environment Science Division, School of Basic Science, Babu \\ Banarasi Das University, India \\ ${ }^{2}$ Department of Botany, University of Lucknow, India
}

Correspondence: Pramod Kumar Singh, Environment Science Division, School of Basic Science, Babu Banarasi Das University, Lucknow-226008, India, Email singh_P_kumari@rediffmail.com

Received:September 14, 2018 | Published: November 0I, 2018
Abbreviations: ESP; exchange sodium percentage, SAR sodium absorption ratio, RWC; relative water content, SWC; specific water content, WSD; water saturation deficit, TCA; trichloro acetic acid, PCA; perchloric acid, FC; folin ciolcalteu, EC; electrical conductivity, CEC; cation exchange capacity, ROS; reactive oxygen species, CAT; catalase, POX; peroxidise, SOD; superoxide dismutase, GR; glutathione reductase

\section{Introduction}

Sodicity referred as high level of $\mathrm{Na}^{+}$in soil while alkalinity is considered as the composites of other salts in soil in which $\mathrm{Na}^{+}$being the predominant one. Thus, salinization poses main cause of threats to cultivatable land which may probably lead to the loss of $30 \%$ of land within the next 25 years and even of $50 \%$ by the year $2050{ }^{1}$ Salt deposition in the soil is affect to plant by changing of the water potential $(\Psi)$ and the ion specific toxicity through disrupting the ion homeostasis of the tissues. ${ }^{2}$ Inadequate water balance and change in osmoticum in tissues causes some changes at cellular and physiological levels. Instead of osmotic stress and ion toxicity other detrimental effects are also showed by plant due to generation of toxic molecules and cellular membrane integrity which initiate a gradual disruption of the cellular mechanism. ${ }^{3}$ Although plants adapt multiple strategies for minimizing salt injury which are based on adjusting the water potential and either exclusion or sequestering the excess salt from sites of metabolism by cell organelles like chloroplast and mitochondria in cells which are very prone to oxidative damage by inducing a high oxidative burst/exposure as it reduces the molecular oxygen and converts it into some over oxidized moieties commonly referred as ROS such as superoxide $\left(\mathrm{O}^{2-}\right)$, peroxide $\left(\mathrm{H}_{2} \mathrm{O}_{2}\right)$, and free radicals $\left(\mathrm{OH}^{-}\right.$ ) which are responsible for rapid cell damage by triggering a chain of reactions and make the plant susceptible to oxidative damage and more vulnerable to salt affecting tissues. ${ }^{3,4}$ The cellular membranes and other macro-molecules, like proteins, nucleic acid, lipids, glycosides, etc., are more sensitive to cytosolic and organelle specific ROS. Cellular impairment in terms of different metabolic events is accelerated by ROS that causes retardation in cellular performance. Depending on the degrees of ROS accumulation in the tissues, plants are also attuned to such oxidative hazards partially or fully depending on over-expression of both non-enzymatic and enzymatic pathways against salinity stress. ${ }^{5}$ A variety of anti-oxidative enzymes, viz. SOD, POX and CAT operate in a sequential cascade reducing the ROS. ${ }^{6-8}$ 
Thus, salinity stress has appeared as possible constraint in the form of oxidative stress to a plant's growth and development. ${ }^{9}$ To meet the internal consumption and for earning foreign exchange, production of medicinal and aromatic plants has to be increased. Present study was one of efforts to exploit the opportunity of cultivation of mango ginger in sodic degraded land to minimize the pressure from fertile land for cultivation like cereals, legumes, oil seed crops and fodder. Literature concerned with tolerance mechanism in mango ginger plants against in sodic stress soil is scarcity except to some workers, worked on medicinal and aromatic plants. ${ }^{10-13}$ Mango ginger is cultivated in Gujarat in India and found wild in parts of other states i.e., West Bengal, U. P, Karnataka and Tamil Nadu. The rhizomes of this plant have highly medicinal value and are useful in different diseases and inflammations. ${ }^{14}$ Rhizomes yield $1 \%$ essential oil containing $18 \% \mathrm{~d}-\alpha$ pinene, $47.2 \%$ ocimene, $11.2 \%$ linalool, 9.1\% linalyl acetate and 9.3\% safrole. ${ }^{15}$ The mashed or grated root is applied externally to the skin in the treatment of ulcers, bruises, wounds and sprains and aromatic root is also used in perfumery. ${ }^{16,17}$ Therefore tolerance mechanism, tolerance limit and quality of mango ginger were assessed by grown in sodic stress soil.

\section{Materials and methods}

Plant materials: Mango ginger (Curcuma amada Roxb.) is a perennial with its very short and thin rhizome with leafy tuft, 60$90 \mathrm{~cm}$ in height. The smell of fresh rhizome contain the smell of green mango and hence known as mango ginger. The plant is occasionally cultivated in tropical areas, especially in India, for its root, which is used medicinally and as a mild ginger spice. ${ }^{16,18}$

\section{Experimentation}

A pot experiment were carried out by growing mango ginger in naturally collected sodic soils from different places at Banthara village near Lucknow-Kanpur High way, Lucknow, U.P., India, having different levels of ESP i.e., control (4.37ESP), low (15.7ESP), medium (35.6ESP) and high (54.5ESP) with four replicates in complete randomized design (CRD). ESP is a standard diagnostic parameter for the sodicity hazard of a soil. The study was conducted in earthen pots to know the tolerance limit of plant at different ESP levels at which plant can easily grow and reproduce. The soil were collected up to $15 \mathrm{~cm}$ depth (surface soils) only and kept it for drying. After drying the soils were thoroughly crushed and properly mixed. The soils were analyzed after processing and chemical properties of soil were indicated in the Table 1 . The earthen clay pots were lined on their inner side alkathene sheets to check the leaching and contamination from the clay of the pots of $15 \mathrm{~kg}$ soils were filled in each pot, 5 rhizome of mango ginger were transplanted in may and thinning as done after germination of plantlets to allow 4 plants to grow in each pot. A basal dose nutrients of $200 \mathrm{mgNkg}^{-1}$ soil as $\mathrm{Ca}\left(\mathrm{NO}_{3}\right)_{2}$ and $100 \mathrm{mgPkg}^{-1}$ soils as $\mathrm{KH}_{2} \mathrm{PO}_{4}$ and $100 \mathrm{mgkg}^{-1}$ soil as $\mathrm{MgSO}_{4}$ were applied to all plant in two split doses during crop growth.

\section{Growth, cell sap pH and EC, plant water relation}

Growth measurement was taken as plant height, rhizome and biomass yield. Plant height was measured from soil surface to young leaf. When plants were about 100 days' old, different parameters of water relation was assessed. The water potential was measured hydrometrically in leaves using Wescor micro-voltmeter and C-52 leaf chambers when the plants were growing at field capacity. The Water Saturation Deficit (WSD) and Specific Water Content (SWC) were calculated following standard procedures. ${ }^{19}$ Simultaneously, cell sap $\mathrm{pH}$ and $\mathrm{EC}$ was determined after homogenization of one gram of fresh leaves in $20 \mathrm{~mL}$ of $0.025 \mathrm{M}$ EDTA solution and reading were taken by ELICO LI $\mathrm{pH}$ meter and GENEI conductivity meter respectively. ${ }^{20}$

Table I Chemical properties of soil which was naturally collected from different location of Banthra, Lucknow used in the experiments before the sowing test plant.

\begin{tabular}{|c|c|c|c|c|}
\hline \multirow{2}{*}{ Soil Properties } & \multicolumn{4}{|l|}{ Soil Sodicity (ESP) } \\
\hline & Control (4.37 ESP) & Low ESP -4.37 & Medium ESP - I 5.75 & High ESP -54.5 \\
\hline Soil pH (I:2 soil water ratio) & $7.98 \pm 0.168$ & $8.50 \pm 0.026$ & $9.54 \pm 0.096$ & $10.13 \pm 0.036$ \\
\hline Soil EC(dSm $\left.{ }^{-1}\right)$ & $0.28 \pm 0.036$ & $0.43 \pm 0.007$ & $0.44 \pm 0.007$ & $0.69 \pm 0.03$ \\
\hline Soil Organic carbon (\%) & $0.43 \pm 0.01$ & $0.36 \pm 0.02$ & $0.14 \pm 0.01$ & $0.09 \pm 0.01$ \\
\hline Exchangeable $\mathrm{Na}\left(\mathrm{cmolkg}^{-1}\right)$ & $0.86 \pm 0.01$ & $2.69 \pm 0.03$ & $4.76 \pm 0.02$ & $7.82 \pm 0.04$ \\
\hline Exchangeable $\mathrm{K}\left(\mathrm{cmolkg}^{-1}\right)$ & $1.9 \pm 0.01$ & $1.02 \pm 0.02$ & $0.59 \pm 0.01$ & $0.50 \pm 0.01$ \\
\hline Exchangeable $\mathrm{Ca}+\mathrm{Mg}\left(\mathrm{cmolkg}^{-1}\right)$ & $10.8 \pm 0.12$ & $10.40 \pm 0.11$ & $9.00 \pm 0.16$ & $8.9 \pm 0.09$ \\
\hline CEC $\left(\mathrm{cmolkg}^{-1}\right)$ & $18.00 \pm 0.43$ & $15.00 \pm 0.34$ & $14.20 \pm 0.26$ & $|3.6 \pm 0.4|$ \\
\hline $\operatorname{ESP}(\%)$ & $4.37 \pm 0.086$ & $|5.73 \pm 0.77|$ & $35.66 \pm 3.549$ & $54.5 \pm 3.49$ \\
\hline SAR & $3.70 \pm 0.40$ & $11.79 \pm 0.36$ & $22.44 \pm 0.42$ & $37.07 \pm 0.56$ \\
\hline Available $\mathrm{K}\left(\mathrm{kg} \mathrm{ha}^{-1}\right)$ & $339.00 \pm 19.31$ & $362.60 \pm 1.32$ & $392 \pm 21.50$ & $394.50 \pm 16.67$ \\
\hline Available $\mathrm{P}\left(\mathrm{kg} \mathrm{ha}^{-1}\right)$ & $41.83 \pm 0.71$ & $31.39 \pm 0.43$ & $23.59 \pm 0.61$ & $19.12 \pm 1.07$ \\
\hline $\mathrm{Fe}(\mathrm{ppm})$ & $7.07 \pm 0.40$ & $8.74 \pm 0.26$ & $8.83 \pm 0.34$ & $9.75 \pm 0.63$ \\
\hline $\mathrm{Zn}(\mathrm{ppm})$ & $0.44 \pm 0.17$ & $0.60 \pm 0.12$ & $0.46 \pm 0.24$ & $0.27 \pm 0.14$ \\
\hline $\mathrm{Cu}$ (ppm) & $1.63 \pm 0.02$ & $0.93 \pm 0.06$ & $0.85 \pm 0.03$ & $0.63 \pm 0.06$ \\
\hline
\end{tabular}

Citation: Singh PK, Pratap SG, Tandon PK. Tolerance of mango ginger (Curcuma amada Roxb.) against sodic stress soil: Effects on growth, rhizome yield, water relation, photosynthetic pigments, antioxidative enzymes, cations and heavy metals concentration. Horticult Int J. 20 I8;2(6):287-297. 


\section{Biomass yield and cations analysis}

Biomass yield was taken at the time of harvest. Uprooted plants were washed and thoroughly separated into root, rhizome and leaves and dried in an oven at $70^{\circ} \mathrm{C}$ for $24 \mathrm{~h}$. Cations concentration were assessed after wet digestion $\left(\mathrm{HNO}_{3}, \mathrm{HCLO}_{4} 10: 1 \mathrm{v} / \mathrm{v}\right.$ mixture $)$ of the oven dried plant material. ${ }^{21}$ The cations $(\mathrm{Na}$ and $\mathrm{K}$ ) were measured on flame photometer while $\mathrm{Fe}, \mathrm{Mn}, \mathrm{Zn}, \mathrm{Cu}$ and $\mathrm{Pb}$ were measured on atomic absorption spectrophotometer (Perkin Elmer Analyst 300).

\section{Photosynthetic pigments}

Photosynthetic pigment i.e., chlorophylls and carotenoid were determined in the extract ( $80 \%$ acetone) of the young fully expanded fourth leaf. ${ }^{22}$ The homogenate was centrifuged at $4000 \mathrm{xg}$ for $10 \mathrm{~min}$ to remove the residue and colour of supernatants were measured at $663.2 ; 646.8$ and $470 \mathrm{~nm}$ for chlorophyll a, chlorophyll b and carotenoid, respectively which have been expressed as mg chlorophyll or carotenoid $\mathrm{g}^{-1}$ fresh weight.

\section{Enzyme extraction}

$2.5 \mathrm{~g}$ of fresh leaf tissue was homogenized in $10.0 \mathrm{~mL}$ of chilled $50 \mathrm{mM}$ potassium phosphate buffer $(\mathrm{pH} 7.0)$ containing $1.0 \%$ insoluble Polyvinyl Pyrrolidone (PVP) using chilled pestle and mortar kept in ice bath. The homogenate was filtered with two-fold muslin cloth and centrifuged at $20000 \mathrm{xg}$ for $10 \mathrm{~min}$ in refrigerated centrifuge at $2^{\circ} \mathrm{C}$. The supernatant was stored at $2^{\circ} \mathrm{C}$ and used for enzyme assays within $4 h$.

\section{Assays of anti-oxidative enzymes}

CAT (EC, 1.11.1.6) activity was assayed in $10 \mathrm{ml}$ of reaction mixture, standardized against $0.1 \mathrm{M} \mathrm{KMnO}_{4}$, containing $0.5 \mathrm{mM} \mathrm{H}_{2} \mathrm{O}_{2}$ and $1 \mathrm{mM}$ phosphate buffer ( $\mathrm{pH} 7.0$ ), was taken in a test tube stabilized at $25^{\circ} \mathrm{C}$ (as described by Bisht, ${ }^{23}$ a modification of the method of Euler and Josephson). The reaction was initiated by adding $1 \mathrm{~mL}$ of tissue extract and the contents were mixed thoroughly. After five minutes the reaction were stopped by addition of $2 \mathrm{~mL}$ of $4 \mathrm{M} \mathrm{H}_{2} \mathrm{SO}_{4} \cdot \mathrm{H}_{2} \mathrm{O}_{2}$ decomposed after $5 \mathrm{~min}$ reaction was assayed by titrating the reaction mixture with $0.1 \mathrm{~N} \mathrm{KMnO}_{4}$. CAT activity is expressed as a unit ( $\mu$ mole $\mathrm{H}_{2} \mathrm{O}_{2}$ decomposed min $^{-1}$ ) mg protein ${ }^{-1}$. POD (EC. 1.11.1.7) was assayed by modification of the Luck $^{24}$ method. $5 \mathrm{~mL} 0.1 \mathrm{M}$ phosphate buffer ( $\mathrm{pH} 6.0), 1 \mathrm{~mL} 0.01 \% \mathrm{H}_{2} \mathrm{O}_{2}$ and $1 \mathrm{~mL} 0.05 \%(\mathrm{w} / \mathrm{v})$ p-phenylene diamine was taken in a centrifuge tube and stabilized at $25^{\circ} \mathrm{C}$. Reaction started by adding $1 \mathrm{~mL}$ of diluted tissue extract and allowed to proceed for $5 \mathrm{~min}$ after which was stopped by adding $2 \mathrm{~mL}$ of $4 \mathrm{~N} \mathrm{H}_{2} \mathrm{SO}_{4}$. Contents were centrifuge at $4000 \mathrm{xg}$ for $15 \mathrm{~min}$ at room temperature. The colour intensity of the supernatant was measured at $485 \mathrm{~nm}$ on spectrophotometer (Spectro-chem MK II Manufactures AIML). The activity of the enzyme has been expressed as a unit (mg protein $)^{-1}$. SOD (EC 1.15.1.1) was determined by measuring the ability to inhibit the photochemical reduction of Nitro-Blue Tetrazolium (NBT) in a $3 \mathrm{~mL}$ reaction mixture containing $50 \mathrm{mM}$ phosphate buffer $\mathrm{pH} 7.8,13 \mathrm{mM}$ methionine, $75 \mu \mathrm{M}$ NBT, $2 \mu \mathrm{M}$ riboflavin, $0.1 \mathrm{mM}$ EDTA and 0 to $50 \mu \mathrm{L}$ enzyme extract. The change in absorbance was measured at $560 \mathrm{~nm}$ (Beauchamp and Fridovich). ${ }^{25}$ Riboflavin was added last and tubes were illuminated for $10 \mathrm{~min}$. Blanks were not illuminated and the above reaction mixture without the enzyme extract developed the maximum colour at $560 \mathrm{~nm}$. GR (EC 1.6.4.2) assay was performed in a $3 \mathrm{~mL}$ reaction mixture containing $100 \mathrm{mM}$ phosphate buffer $\mathrm{pH} 7.0,1 \mathrm{mM}$ GSSG, 1mM EDTA, 0.1mM NADPH and $25-50 \mu \mathrm{L}$ of the enzyme extract. The oxidation of NADPH was followed by monitoring the decrease in absorbance per min at $340 \mathrm{~nm}$. The amount of NADPH oxidized was calculated using the extinction coefficient. ${ }^{26}$ Determination of protein in tissue extracts was made to determine the specific activity of enzyme. Protein was estimated by folin Ciolcalteu reagent of Lowry et al. ${ }^{27}$ in tissue extracts of $20 \%$ chilled Trichloro Acetic Acid (TCA) and allowed to stand for $4 \mathrm{~h}$ at $4^{\circ} \mathrm{C}$. After centrifugation, the residue was solubilized in $0.1 \mathrm{M} \mathrm{NaOH}$ at $80^{\circ} \mathrm{C}$ for $10 \mathrm{~min}$ on water bath and protein was estimated. The colour intensity was measured in spectronic colorimeter at $660 \mathrm{~nm}$. The results have been expressed on percent fresh weight basis.

\section{Estimation of non-enzymatic anti-oxidants}

$\mathrm{H}_{2} \mathrm{O}_{2}$ content was estimated in supernatant prepared by freshly chopped leaf in $100 \%$ chilled acetone and centrifuged at $10,000 \mathrm{~g}$ for $5 \mathrm{~min}$ (Brennan and Frenkel).$^{28}$ The colour intensity was read at $415 \mathrm{~nm}$. The results have been expressed as $\mu \mathrm{mol} \mathrm{H}_{2} \mathrm{O}_{2} \mathrm{~g}^{-1}$ fresh weight. Total Phenol content was determined calorimetrically with Folin Ciolcalteu (FC) reagent in the leaf extract which was shaken thoroughly and made up to $10 \mathrm{~mL}$ using distilled water and $1.5 \mathrm{~mL}$ of $20 \%$ sodium carbonate. ${ }^{29}$ The absorbance of resulting solution was measured at $765 \mathrm{~nm}$ in UV-spectrophotometer. Prolien content was estimated by the method of Bates et al. ${ }^{30}$ Freshly chopped leaves were ground in sulphosalicylic acid and filter with Whatman No.1, a suitable aliquot was taken with ninhydrin reagent and glacial acetic acid and boiled for $1 \mathrm{~h}$. The colour was extracted in toluene and read at $520 \mathrm{~nm}$.

\section{Estimation of sugar, starch and carbohydrates}

For the estimation of sugar and starch, plant material was fixed in boiling $80 \%$ ethanol in the proportion of 1:10. The fixed material was crushed in a pestle and mortar. Alcohol soluble and insoluble fractions were separated by repeated centrifugation at $8,000 \mathrm{~g}$. In the alcohol soluble fractions, sugar was estimated while alcohol insoluble fraction was used for the determination of starch. Sugars were determined calorimetrically by the method of Nelson. ${ }^{31}$ Total sugars i.e., reducing and non-reducing were estimated as reducing sugars after carrying out the enzymatic hydrolysis of the non-reducing sugars for $24 \mathrm{~h}$. The nonreducing sugars were calculated as the difference in the concentration of sugars before and after hydrolysis by invertase. Starch was determined by the method of Montgomery. ${ }^{32}$ The alcohol insoluble material was solubilised in distilled water by boiling on water bath for 15 minutes then macerated in $25 \%$ perchloric acid (PCA) with the help of a glass rod then centrifuge at $5,000 \mathrm{~g}$ for $10 \mathrm{~min}$ and supernatant collected in $50 \mathrm{~mL}$ of $15 \%$ PCA and centrifuged. The process was repeated with 10 and 5\% PCA. Finally, the residue was rejected and all the supernatant fractions combined to made volume. Suitable aliquot was taken and added $0.2 \mathrm{~mL}$ of $80 \%$ phenol. Rapid addition of $5 \mathrm{~mL}$ concentrated sulphuric acid to stop reaction and allowed to cool at room temperature. The colour was read at $490 \mathrm{~nm}$ using $1 \mathrm{~cm}$ cell and blank reagent setting of 0.0 . Starch concentration has been expressed as percentage per unit fresh weight.

\section{Statistics}

Significant difference within the treatments was determined by one way ANOVA using Sigma Stat 3.2. Data are means plus/minus $\mathrm{SE}$ and are significantly difference at $P<0.05$.

\section{Results and discussions}

Some important findings were observed in the present study which was concerned with the morphological, physiological and 
biochemical changes that have justify the tolerance of mango ginger against sodic stress soil. Results indicated that plant height was significantly decreases at medium and high soil ESP level while at low level non significant decrease was observed (Figure 1) (Table 2). Number of tillers was observed higher number than the control at low ESP level, further it was significantly decreases on increasing ESP. Rhizome, tuber and biomass yield were observed insignificant differences than the control while steep decreased were observed at medium and high ESP level (Table 2). Increasing soil ESP affected the survival, growth and metabolic process of mango ginger. Singh et al. ${ }^{17}$ worked on different accession of turmeric grown in sodic soil and reported that accessions varied significantly in terms of plant height, number of leaves and shoots per plant at various stages of crop growth. Similar finding was also observed by Singh et al. ${ }^{7}$ in Osmium species, Singh et al. ${ }^{6} \&$ Garg et al..$^{33}$ in fennel plant who have reported that no detrimental effect was observed up to 25 ESP. Similar type of finding also observed by some other worker. ${ }^{34,35}$ Thus, mango ginger plant can survive up to low ESP without detrimental effect. Thus, it's appearing that medicinal plant can easily grow in low to medium sodic soils which may be an alternative to bioreclaimation of sodic soil and hence more economical than other regular crops. The cell sap $\mathrm{pH}$ was observed higher in control that was non-significantly decreases on increasing the soil sodicity level while EC of cell sap was significantly increases on increasing the soil sodicity (Figure 2A) (Figure 2B) that showed the increased electrolytic contents into the cell sap which also affected water content in the tissues of leaf. RWC was higher at low and medium ESP but it was significantly decreases at high ESP (Figure 2C) while WSD was significantly decreased at low and medium ESP level and further increases at high ESP. The SWC was increased in low and medium ESP than the control but it was decrease at high ESP (Figure 2D) (Figure 2F). Dew point was decreased on increasing the soil ESP (Figure 2E) while water potential significantly increases (showed less negative $\Psi$ ) on increasing soil ESP (Figure 2G). The soil sodicity are responsible for reduced growth at medium and high ESP level which was lead to increased osmotic potential of circulating soils solution and ionic imbalance. In sodic stress condition plant have require more energy for making osmotic adjustments by accumulating organic and inorganic solutes which counteract by lowering the osmotic potential inside their cells than the soil solution of outside. The lost energy in osmotic adjustment results in reduced growth. ${ }^{36}$ Increase in of cell sap pH and EC can be considered as a protective strategy to withstand sodicity stress. This may be due to the synthesis and accumulation of organic acids, which regulate the $\mathrm{pH}$ and $\mathrm{EC}$ of cell $\mathrm{sap}^{37}$ and may be help to maintain osmoticum to withstand sodicity stress. The increased water potential and SWC and decreased in WSD up to medium ESP and increased at high ESP reveals that plant experienced water stress which can be accelerate in water uptake. Similar observations were made some other worker. ${ }^{38,39}$ Increased WSD at high ESP are responsible to increased proline content in the leaf tissue. Proline is accumulated in water stress. ${ }^{40}$

Table 2 Effect of soil sodicity on vegetative growth, rhizome yield and total biomass of Curcuma amada

\begin{tabular}{llllllll}
\hline Treatment & Plant Height $(\mathbf{c m})$ & $\begin{array}{l}\text { No. of } \\
\text { Tillers/ Plant }\end{array}$ & $\begin{array}{l}\text { Rhizome yields } \\
\text { (g/plant) }\end{array}$ & $\begin{array}{l}\text { Tuber yields } \\
\text { (g/plant) }\end{array}$ & $\begin{array}{l}\text { Root yield } \\
\text { (g/plant) }\end{array}$ & $\begin{array}{l}\text { Leaf yield } \\
\text { (g/plant) }\end{array}$ & $\begin{array}{l}\text { Total Biomass } \\
(\mathbf{g} / \text { plant) }\end{array}$ \\
\hline Control & $34.33 \pm 0.722$ & $3.16 \pm 0.601$ & $85 \pm 4.27$ & $91.66 \pm 19.65$ & $22.09 \pm 0.57$ & $85.83 \pm 4.69$ & $284.25 \pm 21.7$ \\
Low ESP & $30.16 \pm 2.833$ & $4 \pm 0.577$ & $72.47 \pm 8.64$ & $79.52 \pm 0.799$ & $14.27 \pm 0.32$ & $79.16 \pm 4.69$ & $245.45 \pm 12.4$ \\
Med ESP & $24.66 \pm 2.186$ & $2 \pm 0.577$ & $26.27 \pm 3.47$ & $15.47 \pm 2.37$ & $8.55 \pm 2.21$ & $25.83 \pm 5.83$ & $72.52 \pm 10.19$ \\
High ESP & $19.53 \pm 0.549$ & $1.3 \pm 0.333$ & $22.29 \pm 5.41$ & $8.2 \pm 0.33$ & $2.389 \pm 0.14$ & $2 \pm 1.15$ & $52.24 \pm 5.12$ \\
\hline
\end{tabular}
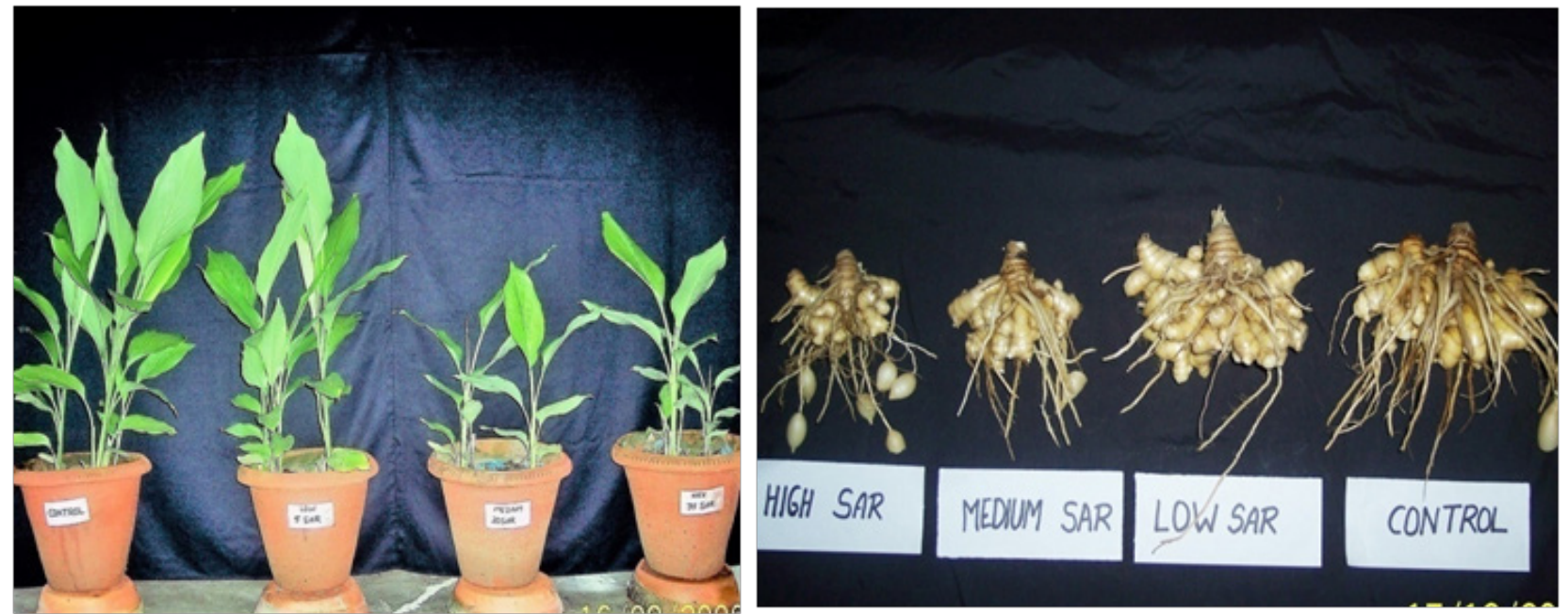

Figure I Effect of soil sodicity on the plant growth and rhizome yield of mango ginger(Curcuma amada).

Citation: Singh PK, Pratap SG, Tandon PK. Tolerance of mango ginger (Curcuma amada Roxb.) against sodic stress soil: Effects on growth, rhizome yield, water relation, photosynthetic pigments, antioxidative enzymes, cations and heavy metals concentration. Horticult Int J. 2018;2(6):287-297. DOI: $10.15406 / \mathrm{hij} .2018 .02 .00066$ 

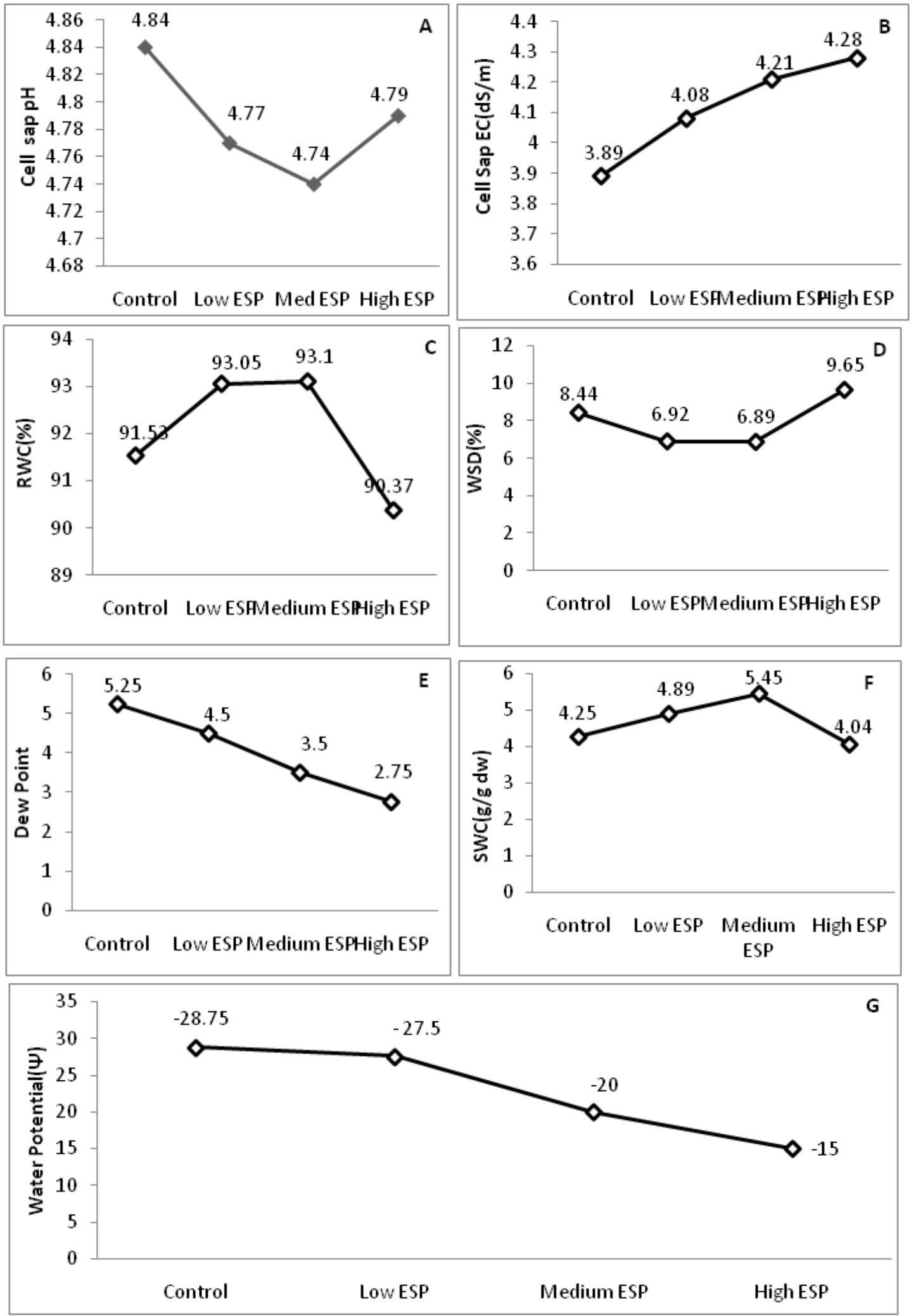

Figure 2 Effect of soil sodicity on the cell sap pH, EC, water relation, water potential ( $\Psi$ : showed negative values) of mango ginger (Curcuma amada).

Citation: Singh PK, Pratap SG, Tandon PK. Tolerance of mango ginger (Curcuma amada Roxb.) against sodic stress soil: Effects on growth, rhizome yield, water relation, photosynthetic pigments, antioxidative enzymes, cations and heavy metals concentration. Horticult Int J. 2018;2(6):287-297. DOI: I0.15406/hij.2018.02.00066 
Photosynthetic pigments i.e., chlorophyll 'a', 'b', total chlorophyll and carotenoid were significantly decreased on increasing soil sodicity (Table 3). Carotenoid chlorophyll ratio was decreased at low ESP level than the control while at medium and high ESP levels increased than the control. The decrease in dry matter production depends on efficiency of photosynthesis that is directly related to the photosynthetic pigments of plants grown at high ESP, which showed decrease in the present study. Similar finding are also observed by other workers. ${ }^{6,7,41,42}$ These reductions in chlorophyll content are related to the enhanced activity of chlorophyllase. ${ }^{43}$ Fine structure of the chlorophyll has been disrupted due to high salinity which is responsible for instability of the pigment protein complex resulting in to reduced chlorophyll contents. ${ }^{44}$ Carotenoid removes free radicals that is generated through excess excitation energy from chlorophyll during photosynthesis. ${ }^{45}$ The carotenoid content was significantly decreased. The carotenoid/chlorophyll ratio was significantly decreased in low and high ESP but slightly increased in medium ESP than the control. There was no clear trend was observed in it. Similar finding was also observed by other worker. ${ }^{6,7}$ Increased carotenoid chlorophyll ratio indicated resistance against sodic stress condition. Anti-oxidative enzymes i.e., CAT, GR and SOD were significantly increased on increasing soil ESP levels (Figures 3B-3D) while POX activity insignificantly decreases up to medium ESP levels (Figure 3A). During plant metabolism, oxygen free radicals are generated and they have required to be removed for maintenance of normal growth. There are many evidences from various plant systems showing the environmental stresses, especially salt stress which alters the amount and the enzyme activities and involved in scavenging of oxygen free radicals. The primary scavenger is the enzyme i.e., SOD to hydrogen peroxide which is eliminated by ascorbate peroxidase, at the expense of oxidizing ascorbate to monodehydroascorbate. These two enzymes are found in several isozymes which are active in the chloroplast and the cytosol ${ }^{46}$ In present study, CAT, GR and SOD were significantly increased while POX activity insignificantly decreases up to medium ESP levels that showed tolerance against sodic stress environment. Inactivation of POX was possibly due to enhancement of $\mathrm{H}_{2} \mathrm{O}_{2}$ levels. Similar finding was also observed by other workers ${ }^{47-49}$ in different plants and observed that SOD activity was unregulated due to production of $\mathrm{H}_{2} \mathrm{O}_{2}$ after salinity treatment. Total CAT activity decreased with increasing salinity in Crithmum maritimum and mangroves which showed that CAT respond similarly in glycophytes as well as halophytes in salinity stress conditions. The POX is also involved in to her plant defence mechanisms, including responses to insect ${ }^{50,51}$ and in a coordinated response known as the oxidative burst. $^{52,53}$ Similar finding was also observed by different workers. ${ }^{49,48,53}$ Thus, SOD showed the first line of defence against oxidative stress in plants and causes dismutation of superoxide radicals at almost diffusion-limited rates to produce $\mathrm{H}_{2} \mathrm{O}_{2}{ }^{50}$ It plays an important part in determining the concentration of $\mathrm{O}_{2}$ and $\mathrm{H}_{2} \mathrm{O}_{2}$ in plants and hence performs a key role in the defence mechanism against free-radical toxicity. ${ }^{54}$ Similar trend were also observed by several workers. ${ }^{55-59}$ Thus, presence of a strong antioxidative response mechanism combined with physiological specialization in the mango ginger plant contributes to the defence in sodicity tolerance capacity. Some non enzymatic anti-oxidants like total phenols and prolien contents were significantly increased than the control on increasing soil sodicity (Figure 4B) (Figure 4C) while $\mathrm{H}_{2} \mathrm{O}_{2}$ content was insignificantly decreases at low ESP and medium ESP (Figure 4A).

Table 3 Effect of soil sodicity on photosynthetic pigments in leaf of Curcuma amada

\begin{tabular}{llllll}
\hline Treatment & $\begin{array}{l}\text { Chlorophyll 'a } \\
(\mathbf{m g} / \mathbf{g} \text { FW) }\end{array}$ & $\begin{array}{l}\text { Chlorophyll 'b } \\
(\mathbf{m g} / \mathbf{g} \text { FW) }\end{array}$ & $\begin{array}{l}\text { Total Chlorophyll } \\
(\mathbf{m g} / \mathbf{g} \text { FW) }\end{array}$ & $\begin{array}{l}\text { Carotenoid } \\
(\mathbf{m g} / \mathbf{g} \text { FW) }\end{array}$ & $\begin{array}{l}\text { Carotenoid/ } \\
\text { Chlorophyll Ratio }\end{array}$ \\
\hline Control & $0.843 \pm 0.01$ & $0.63 \pm 0.019$ & $1.473 \pm 0.02$ & $0.835 \pm 0.0127$ & $0.566 \pm 0.016$ \\
Low ESP & $0.81 \pm 0.008$ & $0.469 \pm 0.027$ & $1.503 \pm 0.03$ & $0.662 \pm 0.02$ & $0.44 \pm 0.025$ \\
Med ESP & $0.671 \pm 0.021$ & $0.424 \pm 0.013$ & $1.095 \pm 0.015$ & $0.664 \pm 0.013$ & $0.606 \pm 0.014$ \\
High ESP & $0.668 \pm 0.035$ & $0.416 \pm 0.005$ & $1.084 \pm 0.012$ & $0.578 \pm 0.05$ & $0.533 \pm 0.031$ \\
\hline
\end{tabular}
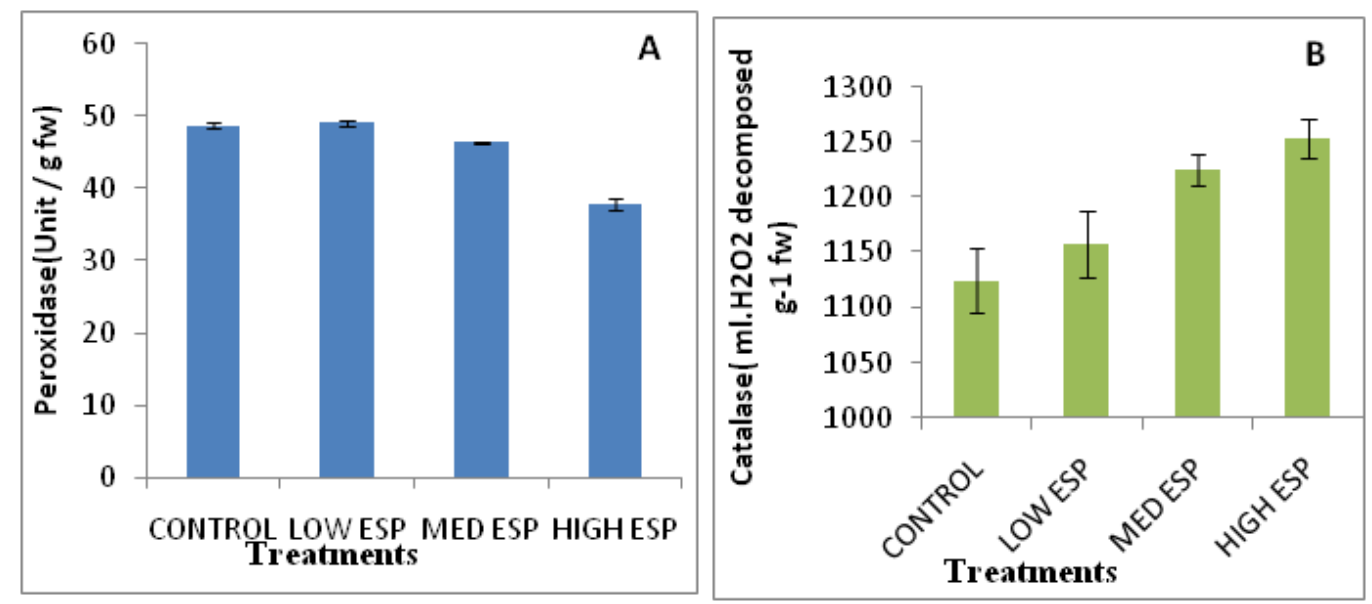

Citation: Singh PK, Pratap SG, Tandon PK. Tolerance of mango ginger (Curcuma amada Roxb.) against sodic stress soil: Effects on growth, rhizome yield, water relation, photosynthetic pigments, antioxidative enzymes, cations and heavy metals concentration. Horticult Int J. 20I8;2(6):287-297. 
Figure Continued..

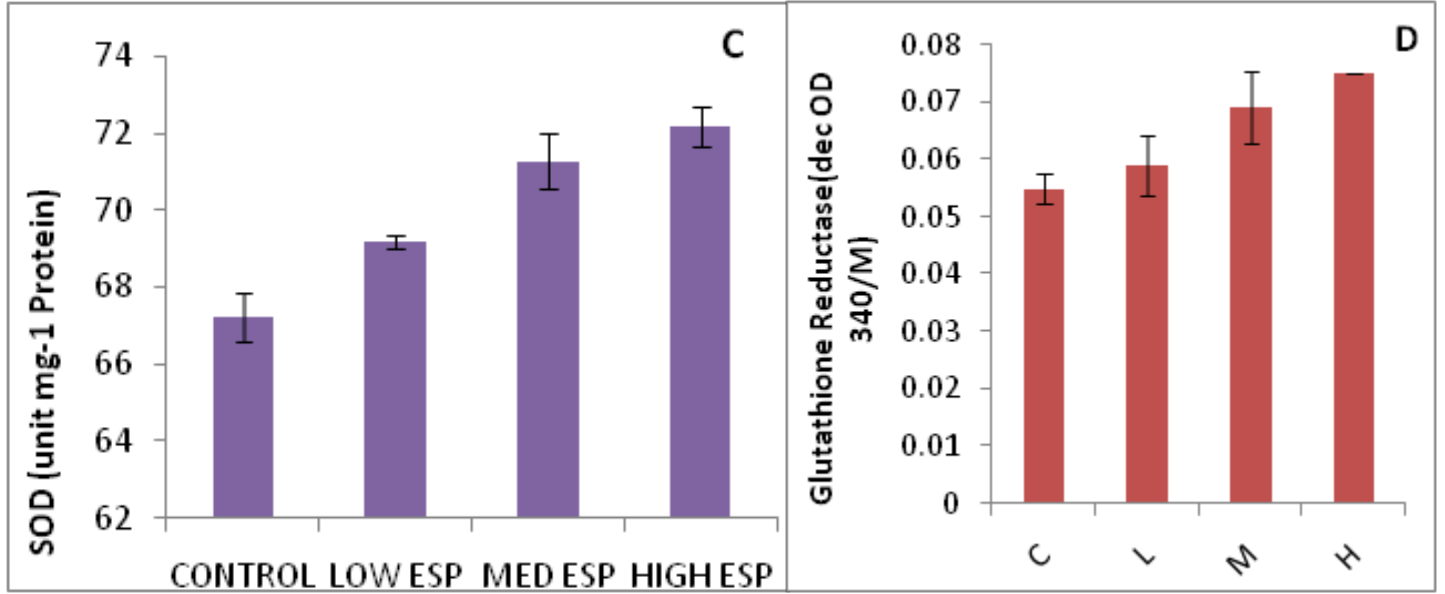

Figure 3 Effect of sodicity on anti-oxidatives enzymes (A; peroxidase, B; catalase, C;superoxide dismutase, D; glutathione reductase) of Curcuma amada.
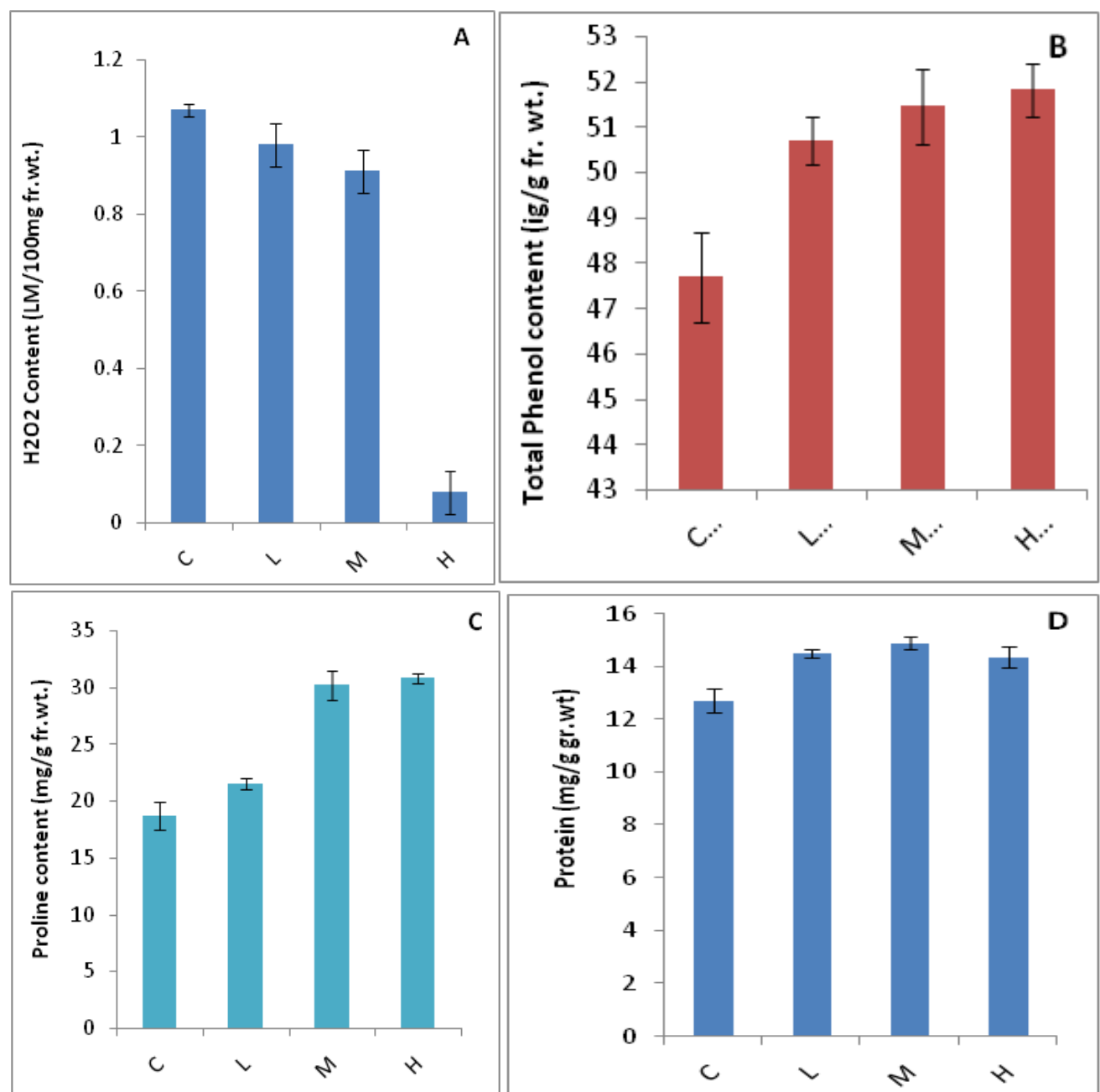

Figure 4 Effect of soil sodicity on non-enzymatic anti-oxidant contents like $\mathrm{A} ; \mathrm{H}_{2} \mathrm{O}_{2}$, B; total phenol and C; proline contents and some qualitative contents like $\mathrm{D}$; protein, E; reducing sugar and F; total carbohydrates of Curcuma amada. 
Non-enzymatic antioxidants (e.g., ascorbic acid, glutathione, tocopherol and carotenoid) play a key role in scavenging free radicals in plants during salinity stress. ${ }^{45,60}$ Carotenoid scavenges free radicals that are generated owing to excess excitation energy from chlorophyll during photosynthesis. ${ }^{45}$ Some osmolytes play an important functional role by synthesizing a metabolite (e.g., algras, polyols, amino acids and tertiary and quaternary ammonium and sulphonium compounds) in osmotic adjustment under hyper osmotic stress caused by salinity stress. ${ }^{61,62}$ Prolien is a stress protein which accumulation in the plant showed tolerance against stress. In the present study, revealed that prolien content accumulation was increased on increasing the sodicity in mango ginger plant. Maximum prolien content was observed in the plant grown in high ESP while minimum in control. Similar finding also observed by other worker and observed that compatible solutes are involved in protection against free radicals during stress conditions ${ }^{62}$. However, recent studies suggest a link between increased osmolyte content (e.g., prolien) in halophytes with decreased ROS production which showed better tolerance against salt stress. Prolien is a good osmoticum and helps in membrane stability ${ }^{63}$ which showed a correlation between increased proline content and improved tolerance to abiotic stress. ${ }^{48,64}$ It also scavenges singlet oxygen and free-radical-induced damages in plants and performs an important role in protection of proteins against denaturation. ${ }^{65}$ Some qualitative materials like reducing sugar, carbohydrates and protein contents were assessed in the leaf tissues which indicated that reducing sugar was significantly decreased than the control on increasing soil sodicity but significant differences were observed in between low, medium and high ESP level (Figure 4E) while total carbohydrate was significantly increases on increasing soil sodicity (Figure 4F). Other workers are also observed similar finding ${ }^{7}$ in Ocimum aromatic plant observed that reducing sugars significantly decreases than the control on increasing sodicity while total carbohydrate was significantly increases. Sugar alcohols (e.g., pinitol) play an important role in intracellular osmotic adjustment as well as in scavenging free radicals which accumulates in response to salinity stress. ${ }^{66}$ Protein content was observed higher than the control but there was no significant difference was observed between low, medium and high ESP level (Figure 4D). Thus it appears that in sodic stress condition reducing sugars convert in carbohydrates, on the basis of these finding we can say that Curcuma amada shows tolerance against sodic stress environment. Sodium
(Na) was analysed in different plant parts of plant that indicated that maximum concentration of $\mathrm{Na}$ was observed in leaf and least was observed in rhizome (Figure 5A). The concentration of $\mathrm{Na}$ was significantly increases on increasing the soil sodicity in all parts of plant while potassium $(\mathrm{K})$ concentration was observed maximum in rhizome and minimum in tuber (Figure 5B). Increasing trend of $\mathrm{K}$ was observed in low and medium ESP levels than the control while at high ESP level it was steeply decreased in all parts of plant. $\mathrm{Na} / \mathrm{K}$ ratio least observed least in rhizome while highest in root (Figure 5C). Decreasing trends was observed up to medium ESP level but sharp increased at ESP level in all plant parts. Although $\mathrm{Na} / \mathrm{K}$ ratio was within the limit $(<1.0)$ in all parts of plant. Accumulation of $\mathrm{Na}^{+}$ion secondarily induces the membrane injury due to loss of electrolytes and $\mathrm{K}^{+}$ion. ${ }^{14}$ Thus, the $\mathrm{K}^{+}$loss under salinity stress condition is most important ion for osmo-regulation in leaf tissues. Highest iron $(\mathrm{Fe})$ concentration was observed in leaf and root while least in rhizome (Figure 5D). Initially at low level Fe was higher than the control in all plant parts further at medium and high ESP level it was insignificantly decreased. Manganese (Mn) concentration was significantly increases up to medium ESP level than the control which was further decreased at high ESP level (Figure 5E). Highest copper $(\mathrm{Cu})$ concentration was observed in root which was significantly decreased on increasing soil sodicity (Figure 5F). Zinc (Zn) concentration was observed maximum in leaf which was significantly decreases on increasing soil sodicity and similar trend was observed in rhizome and root while least $\mathrm{Zn}$ was observed in tuber which was increases on increasing soil sodicity (Figure 5G).

Exchangeable sodium caused in the absorption of sodium, nitrogen and molybdenum and a decrease in the absorption of calcium, potassium, sulfur, manganese of $\mathrm{Ca}, \mathrm{Mg}, \mathrm{K}$ in different plant parts as well as total uptake decreased with increase in exchangeable sodium in root zone of the plant has been reported by various workers. ${ }^{6,67-69}$ Lead $(\mathrm{Pb})$ concentration was observed least in rhizome which was significantly increases on increasing soil sodicity while in leaf, root and tuber it were increases at low and medium ESP while it was decreased at high ESP (Figure 5H). The problem of $\mathrm{Zn}, \mathrm{Fe}$ and $\mathrm{Cu}$ uptake is very acute under sodic conditions where carbonate and bicarbonate are supposed to be major anions interfering with their availability and may cause precipitation of these nutrients as insoluble salts due to high soil $\mathrm{pH}$.
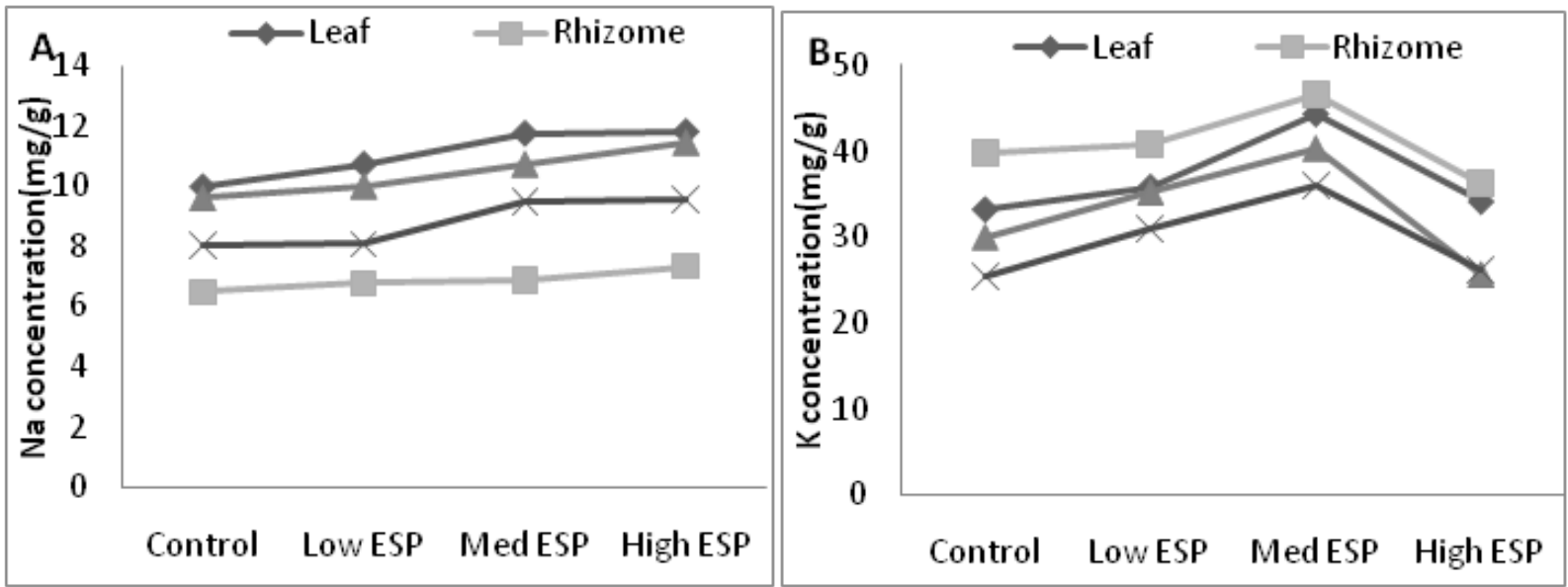

Citation: Singh PK, Pratap SG, Tandon PK. Tolerance of mango ginger (Curcuma amada Roxb.) against sodic stress soil: Effects on growth, rhizome yield, water relation, photosynthetic pigments, antioxidative enzymes, cations and heavy metals concentration. Horticult Int J. 2018;2(6):287-297. 

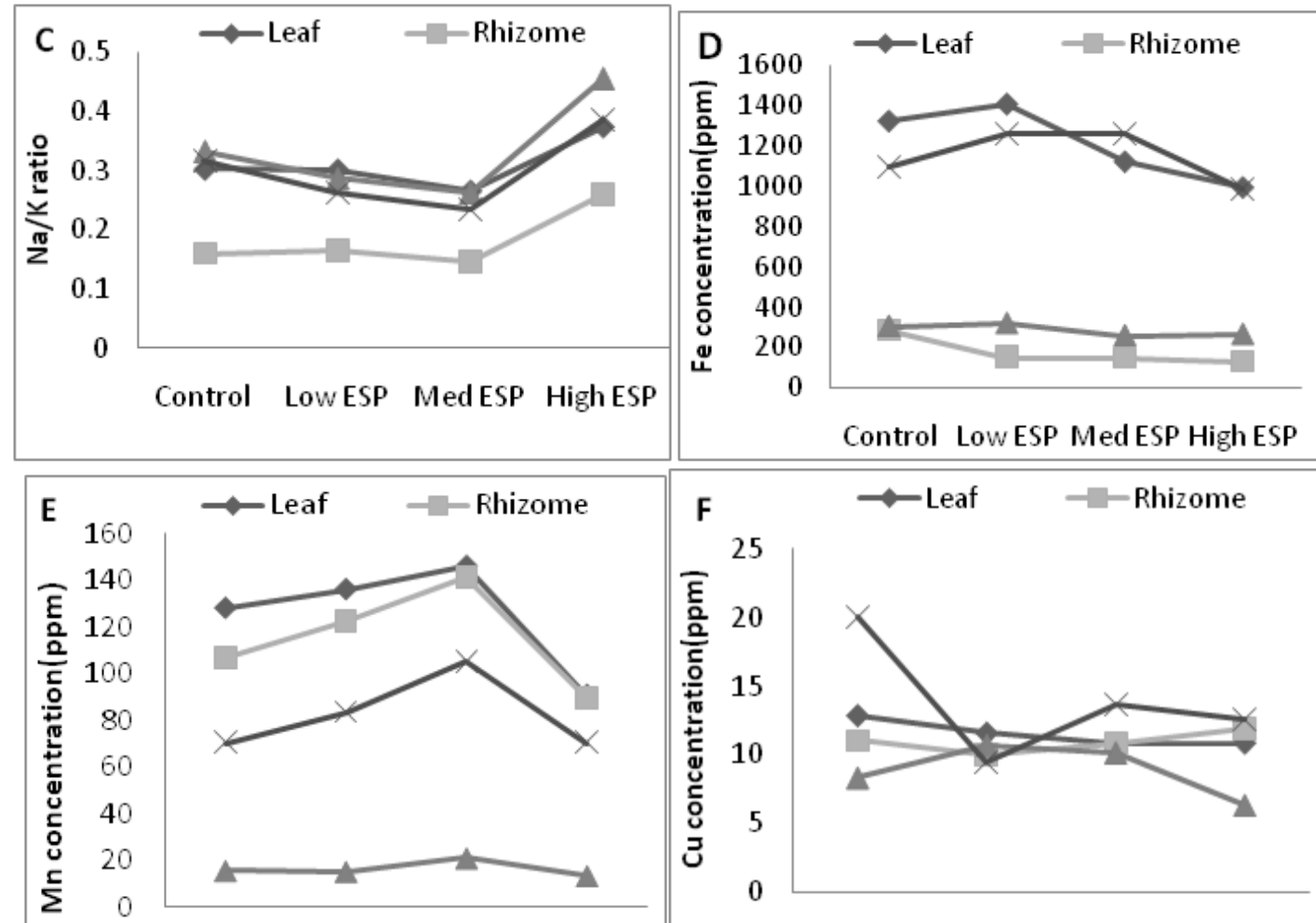

Control Low ESP Med ESPHigh ESP

Control LowESP MedESP High ESP
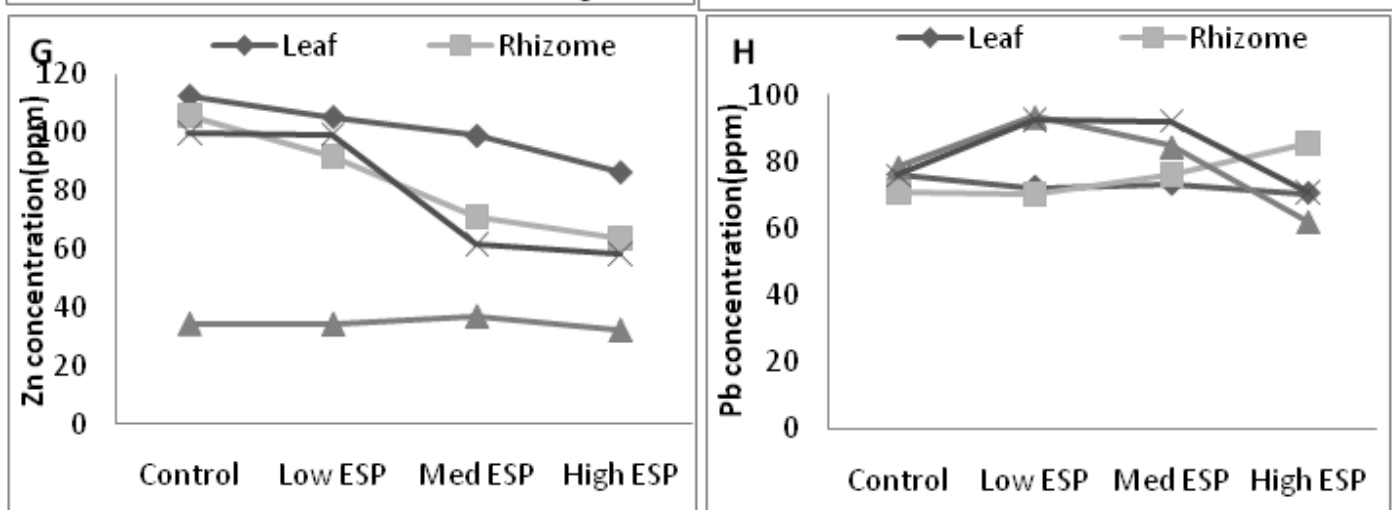

Figure 5 Effect of soil sodicity on cations ( $\mathrm{Na}$ and $\mathrm{K}$ ions) and heavy metals (Fe, Mn, $\mathrm{Cu}$, Zn and Pb) concentration in different plant parts of mango ginger (Curcuma amada).

\section{Conclusion}

Mango ginger is perennial herb having light creamy yellow rhizome and sour with aromatic taste like green mango which have highly medicinal value and are useful in different diseases. It is cultivated throughout India. To meet the internal consumption and for earning foreign exchange, production of medicinal and aromatic plants has to be increased. Present study was one of efforts to exploit the opportunity of cultivation of mango ginger or ama haldi (Curcuma amada) in sodic degraded land. Mango ginger showed tolerance against sodic stress soil up to low to medium levels of ESP without deteriorating rhizome yield and quality while at medium and high ESP level showed defence mechanism by electrolytic balance, increasing water potential, increasing activities of antioxidant enzymes and non-enzymatic anti-oxidant. So, it was highly recommended to grow mango ginger in moderately sodic degraded land or reclaimed sodic land that can be suitable economical than the other traditional crops.

\section{Acknowledgements}

The author is thankful to Department of Science and Technology (DST), New Delhi for financial assistance through SERC Fast Track Scheme (SR/FT/L-172/2004). 


\section{Conflict of interest}

Authors declare that there is no conflict of interest.

\section{References}

1. Yokoi S, Bressan RA, Hasegawa PM. Salt stress tolerance of plants JIRCAS working report. 2002;25-33.

2. Zhu JK. Plant salt tolerance. Trends Plant Sci. 2001;6(2):66-71.

3. Basu S, Roychowdhury A, Saha P, et al. Differential antioxidative responses of indica rice cultivars to drought stress. Plant Growth Regul. 2009;10:219-225.

4. Bascola PR, Menossi M, Jorge RA. Aluminum-induced oxidative stress in plants. Photochemistry. 2003;62(2):181-189.

5. Wang W, Kin YH, Haeng LS, et al. Differential antioxidation activities in two alfa cultivars under chilling stress. Plant Biotechnol Rep. 2009;3(4):301-307.

6. Singh PK, Kumar P, Tandon PK. Soil sodicity alters antioxidative enzymes, photosynthetic pigments, water content and essential oil quality of fennel (Foeniculum vulgare Mill.). Res J Soil Biol. 2014;6(1):1-16.

7. Singh PK, Verma NS, Pandey N et al. Soil sodicity induced changes in aromatic plants: effects on growth, water relation, photosynthetic pigments, antioxidative enzymes, cations concentration and quality of Ocimum sanctum. Res J Med Plant. 2015;9(8):375-394.

8. Sairam RK, Tyagi A. Physiology and molecular biology in salinity tolerance in plants. Curr Sci. 2004;86(3):407-420.

9. Roy Choudhury A, Basu S. Over expression of an abiotic stress responsive plant protein in bacteria Escherichia coli. Afr J Plant Biotechnol. 2008;7(18):3231-3234.

10. Ghosh N, Adak MK, Ghosh PD, et al. Differential responses of two rice varieties to salt stress. Plant Biotechnol Rep. 2011;5(1):89-103.

11. Garg VK, Singh PK, Pushpangadan P. Exchangeable sodium induced changes in yield, water relation and cation composition of fennel (Foeniculum vulgare Mill). J Environ Biol. 2005;26(2 Suppl):335-340.

12. Singh PK, Chowdhury AR, Garg VK. Yield and analysis of essential oil of some spice crops grown in sodic soils. Indian Perf. 2002;46:35-40.

13. Singh S, Niranjan A, Sharma SK, et al. Curcuminoids, phenolic contents and yield investigations of Curcuma longa L. accessions, grown on partially reclaimed sodic soil. Med Plants. 2011;3(3):1-5.

14. Warrier PK, Nambiar VPK, Ramankutty C. Indian Medicinal Plants: A Compendium of 500 Species - 5 Volumes. Madras: Orient Longman Ltd; 1994;1-5.

15. Chopra RN, Nayar SL, Chopra IC. Glossary of Indian Medicinal Plants. India: CSIR; 1980.

16. Huxley A. The new RHS dictionary of gardening. MacMillan Press; 1992.

17. Husain A, Virmani OP, Popli SP, et al. Dictionary of Indian Medicinal Plants. India: CIMAP; 1992. 546 p.

18. Chevallier A. The Encyclopedia of Medicinal Plants. London: Dorling Kindersley; 1996. 336 p.

19. Barrs HD, Weatherley PE. A re-examination of the relative turgidity technique for estimating water deficits in leaves. Aust J Biol Sci. 1962;15:413-428.

20. Dwivedi RS, Joshi YS, Qadar A, et al. Developing the parameters for salt tolerance in the case of wheat crop. Proceedings of the International Symposium on Salt Affected Soils. Central Soil Salinity Research Institute; 1980:494-500.
21. Piper CS. Soil Plant Analysis. India: Asia Publishing House; 1967.

22. Lichtehthaler HK, Chlorophylls and Carotenoid: Pigments of Photosynthetic Biomembranes. In: Methods in Enzymology, Paecker L, R Douce, Editors. Academic Press. 1987;148:350-382.

23. Bisht SS. Effect of heavy metals on plant metabolism. Lucknow: Lucknow University; 1972.

24. Luck H, Peroxidase. In: Methods of Enzymatic Analysis, Bergmeyer HU, Editor. USA: Academic Press; 1963;895-897.

25. Beauchamp C, Fridovich I. Superoxide dismutase: Improved assays and an assay applicable to acrylamide gels. Anal Biochem. 1971;44(1):276287.

26. Jablonski PP, Anderson JW. Light-dependent reduction of oxidized glutathione by ruptured chloroplasts. Plant Physiol. 1978;61(2):221-225.

27. Lowry OH, Rosebrough NJ, Farr AL, et al. Protein measurement with the Folin phenol reagent. J Biol Chem. 1951;193:265-275.

28. Brennan T, Frenkel C. Involvement of hydrogen peroxide in the regulation of senescence in pear. Plant Physiol. 1977;59(3):411-416.

29. Kumaran A, Karunakaran RJ. In vitro antioxidant activities of methanol extracts of five Phyllanthus species from India. LWT-Food Sci Technol. 2007;40:344-352.

30. Bates LS, Waldren RP, Teare ID. Rapid determination of free prolien for water-stress studies. Plant Soil. 1973;39:205-207.

31. Nelson N. A photometric adaptation of the Somogyi method for the determination of glucose. J Biol Chem. 1944;153:375-380.

32. Montgomery R. Determination of glycogen. Archs Biochem. Biophys. 1957;67:378-386.

33. Garg VK, Singh PK, Pushpangadan P. Exchangeable sodium induced changes in yield, water relation and cation composition of fennel (Foeniculum vulgare Mill). J Environ Biol. 2005;26(2 Suppl):335-340.

34. Qadar A. Requirement of rice crop for phosphorus and potassium at varying sodicity levels. J Plant Nutr. 1995;18:2291-2303.

35. Garg VK, Singh PK, Katiyar RS. Yield and nutrient uptake by some species crops grown in sodic soil. Proceedings of the Centennial Conference on Species and Aromatic Plants. India; 2000:133-138.

36. Brady NC, Weil RR. Soils of Dry Regions: Alkalinity Salinity and Sodicity. In: The nature and property of soils. Brady NC, RR Weil Edior. $13^{\text {th }}$ Edition. Singapore: Pearson Education Pt. Ltd; 2002:412-448.

37. Dwivedi RS, Randhawa NS, Bansal RL. Phosphorus-zinc interaction. Plant Soil. 1975;43(1-3):639-648.

38. Khan MA, Irwin AU, Showalter AM. Effects of salinity on growth, water relations and ion accumulation of the subtropical perennial halophyte, Atriplex griffithii var. stocksii. Ann Bot. 2000;85(2):225-232.

39. Khan MA, Gul B, Weber DJ. Effect of salinity on the growth and ion content of Salicornia rubra. Commun Soil Sci Plant Anal. 2001;32:29652977.

40. Carceller M, Fraschina A. The free proline content of water stressed maize roots. Z Pflanzenphysiol. 1980;100(1):43-49.

41. El Sharkawi HM, Salame FM, Mazen AA. Chlorophyll response to salinity, sodicity and heat stresses in cotton, rama and millet. Photosynthetica. 1986;20:204-211.

42. Tewari TN, Singh BB. Stress studies in lentil (Lens esculenta Moench). II. Sodicity induced changes in chlorophyll, nitrate and nitrite reductase, nucleic acids, prolien, yield and yield components in lentil. Plant Soil. 1991;136(2):225-230. 
43. Reddy MP, Vora AB. Changes in pigment composition, Hill reaction activity and saccharides metabolism in Bajra (Pennisetum typhoides $\mathrm{S}$ and H) leaves under $\mathrm{NaCl}$ salinity. Photosynthetica. 1986;20:50-55.

44. Lapina IP, Popov BA. The effect of sodium chloride on the photosynthetic apparatus of tomatoes. Fiziologiya Rastenii. 1970;17:580-584.

45. Arora A, Sairam RK, Srivastava GC. Oxidative stress and antioxidative systems in plants. Cur Sci. 2002;82(10):1227-1238.

46. Asada K. Production and action of active oxygen species in photosynthetic tissue. In: Causes of Photo-Oxidative Stress and Amelioration of Defense Systems in Plants. Foyer CH, P Mullineaux Editors. CRC Press; 1994:77104.

47. Parida AK, Das AB, Mohanty P. Defense potentials to $\mathrm{NaCl}$ in a mangrove, Bruguiera parviflora: Differential changes of isoforms of some antioxidative enzymes. J Plant Physiol. 2004;161:531-542.

48. Cherian S, Reddy MP. Evaluation of $\mathrm{NaCl}$ tolerance in the callus cultures of Suaeda nudiflora Moq. Boil Plant. 2003;46:193-198.

49. Amor NB, Hamed KB, Debez A, et al. Physiological and antioxidan responses of the perennial halophyte Crithmum maritimum to salinity. Plant Sci. 2005;168(4):889-899.

50. Salin ML. Toxic oxygen species and protective systems of the chloroplast Physiol Plant. 1988;72(3):681-689.

51. Bi JL, Felton GW. Foliar oxidative stress and insect herbivory: Primary compounds, secondary metabolites and reactive oxygen species as components of induced resistance. J Chem Ecol. 1995;21(10):1511-1530.

52. Kawano T. Roles of the reactive oxygen species-generating peroxidase reactions in plant defense and growth induction. Plant Cell Rep. 2003;21(9):829-837.

53. Cherian S, Reddy MP, Pandya JB. Studies on salt tolerance in A. marina (forsk) Viem. Effect of Nacl salinity on growth, ion accumulation and enzyme activity. Indian J Plant Physiol. 1999;4:266-270.

54. Bowler C, Montagu MV, Inze D. Superoxide dismutase and stress tolerance. Annu Rev Plant Physiol Mol Biol.1992;43:83-116.

55. Hernandez JA, Campillo A, Jimenez A, et al. Response of antioxidan systems and leaf water relations to $\mathrm{NaCl}$ stress in pea plants. New Phytol. 1999;141(2):241-251.

56. Gosset DR, Millhollon EP, Lucas MC, et al. Antioxidant response to $\mathrm{NaCl}$ stress in salt-tolerant and salt-sensitive cultivars of cotton. Crop Sci. 1994;34:706-714.
57. Mittova V, Tal M, Volokita M, et al. Up-regulation of the leaf mitochondrial and peroxisomal antioxidative systems in response to salt-induced oxidative stress in the wild salttolerant tomato species Lycopersicon pennellii. Plant Cell Environ. 2003;26(6):845-856.

58. Takemura Hanagata $\mathrm{T}$ N, Sugihara K, Baba S, et al. Physiological and biochemical responses to salt stress in the mangrove, Bruguiera gymnorrhiza. Aquatic Bot. 2000;68(1):15-28.

59. Parida $\mathrm{AK}$, Das $\mathrm{AB}$, Mohanty P. Defense potentials to $\mathrm{NaCl}$ in a mangrove, Bruguiera parviflora: Differential changes of isoforms of some antioxidative enzymes. J Plant Physiol. 2004;161(5):531-542.

60. May M, Vernoux T, Leaver C, et al. Glutathione homeostasis in plants: Implications for environmental sensing and plant development. J Exp Bot. 1998;49(321):649-667.

61. Yancey PH, Clark ME, Hand SC, et al. Living with water stress: Evolution of osmolyte systems. Science. 1982;217(4566):1214-1222.

62. Chen THH, N Murata. Enhancement of tolerance of abiotic stress by metabolic engineering of betaines and other compatible solutes. Curr Opin Plant Biol. 2002;5(3):250-257.

63. Hanson AD, Burnet M. Evolution and metabolic engineering of osmo protectant accumulation in higher plants. In: Biochemical and Cellular Mechanisms of Stress Tolerance in Plants. Cherry JH Editor. Berlin: Springer; 1994:291-301.

64. Matysik J, Alia B, Bhalu, et al. Molecular mechanisms of quenching of reactive oxygen species by proline under stress in plants. Curr Sci. 2002;82(5):525-532.

65. Alia P, Saradhi P, Mohanty P. Proline enhances primary photochemical activities in isolated thylakoid membranes of Brassica juncea by arresting photoinhibitory damage. Biochem Biophys Res Commun.1991;181(3):1238-1244.

66. Vernon DM, Bohnert HJ. A novel methyl transferase induced by osmotic stress in the facultative halophyte Mesembryanthemum crystallinum. EMBO J. 1992;11(6):2077-2085.

67. Das SK, Mehrotra CL. Salt tolerance of some agricultural crops during early growth stages. Indian J Agric Sci. 1971;41:882-888.

68. Odar A. Effect of seedling age of two rice varieties on their sodicity tolerance. Indian J Plant Physiol. 1990;33:162-164.

69. Botrini L, Graifenberg A, di Paola ML. Potassium affects sodium content in tomato plants grown in hydroponic cultivation under saline-sodic stress. Hort Science. 2000;35:1220-1222.

Citation: Singh PK, Pratap SG, Tandon PK. Tolerance of mango ginger (Curcuma amada Roxb.) against sodic stress soil: Effects on growth, rhizome yield, water relation, photosynthetic pigments, antioxidative enzymes, cations and heavy metals concentration. Horticult Int J. 20 I8;2(6):287-297. 